\title{
Literatura pedagogiczna w repertuarze wydawców poznańskich XIX wieku
}

Przystępując do omówienia tytułowego zagadnienia, zacznę od doprecyzowania użytych w nim terminów. Pod pojęciem literatura pedagogiczna ujmuję całą produkcję wydawniczą adresowaną dla potrzeb szkoły, tj. książki przeznaczone dla dzieci i młodzieży oraz pozycje dla nauczycieli, a także dotyczące organizacji szkół, zasad ich funkcjonowania, problematyki oświaty, wychowania, ale od strony zagadnień związanych ze szkolnictwem ${ }^{1}$. Pozycje dotyczące tej ostatniej problematyki rozpatrywanej z punktu widzenia wyłącznie zagadnień społeczno-politycznych nie zostały ujęte, choć trzeba mieć świadomość często bardzo wąskich granic rozdzielających przynależność danych tytułów do jednej lub drugiej grupy. W badaniach nie uwzględniono wydawnictw ciągłych, a więc czasopiśmiennictwa specjalistycznego i sprawozdań szkolnych. Mówiąc o wydawcach, zamierzam skupić się na grupie osób zawodowo zajmujących się wydawaniem książek, z uwzględnieniem także tych podmiotów, które do tej grupy nie należą, choć na niwie edytowania książek z tego zakresu działały. Krótkiego wyjaśnienia wymaga także zakres czasowy określenia XIX wiek. W badaniach dotyczących ka $38 / 40$.

* Dr hab., dyrektor Biblioteki Uniwersyteckiej UAM w Poznaniu, 61-816 Poznań, ul. Ratajcza-

1 Problematyka produkcji książek dla dzieci i młodzieży oraz nauczycieli nie została w literaturze przedmiotu w odniesieniu do Poznania i Wielkopolski omówiona. Stefan Truchim w opracowaniu Historia szkolnictwa i oświaty polskiej w Wielkim Księstwie Poznańskim, t. 1-2, Łódź 1967-1968, o używanych podręcznikach pisał mało, podobnie jak J. Stoiński w książce Szkolnictwo średnie w Wielkim Księstwie Poznańskim w I połowie XIX wieku (1815-1850), Poznań 1972. Najwięcej na temat podręczników do nauki języka polskiego pisał Lech Słowiński, do którego pracy będę się odwoływał. W odniesieniu do historii pewne elementy znajdziemy w opracowaniu Alicji Hinc, Obraz dziejów ojczystych w pozaszkolnej edukacji historycznej społeczeństwa polskiego w Wielkim Księstwie Poznańskiem w pierwszej połowie XIX wieku, Poznań 2007. Najnowsze omówienie problematyki rozwoju szkolnictwa odnajdujemy w pracy Witolda Molika Inteligencja polska w Poznańskiem w XIX i początkach XX wieku, Poznań 2009, s. 109-168. 
Poznania umownie przyjęto obejmować nim lata 1815-1914, tj. okres od powstania Wielkiego Księstwa Poznańskiego aż do wybuchu I wojny światowej. Jest to okres zamknięty, w którym dokonały się różnorakie przemiany pozwalające wyraźnie odróżnić go od pierwszych lat XIX stulecia, jeszcze związanych z wydarzeniami poprzedniej epoki.

Próbując skonstruować wypowiedź na wskazany temat, postaram się w pierwszej części zwrócić uwagę na pewne problemy dostrzegane szczególnie z punktu widzenia bibliologii. Starać się będę wskazywać tematykę wymagającą zbadania w celu odpowiedzenia na pytania o rolę wydawców, miejsce książki szkolnej, czy szerzej - pedagogicznej, w ówczesnym repertuarze wydawniczym.

Osadzając ruch wydawniczy w zakresie książki pedagogicznej na tle całego ruchu wydawniczego, należy powiedzieć, iż dla lat 1815-1914 zarejestrowano dla Poznania blisko 11700 wydanych tytułów². Produkcja ta, osiągnięta w ciągu stulecia, w poszczególnych jego dziesięcioleciach rozwijała się dynamicznie. Z jednej strony zauważyć można systematyczny jej wzrost, co jest zjawiskiem zrozumiałym, gdyż odpowiada ogólnym tendencjom rozwoju społeczeństwa w różnych tegoż rozwoju przejawach. Jednakże zauważamy, że nie był to wzrost jednostajny, ale podlegający pewnym wahaniom. Poniższa tabela pokazuje rozmiary produkcji wydawniczej w Poznaniu w kontekście produkcji rejestrowanej dla ziem dawnej Polski, wraz z wyliczeniem udziału Poznania w całej produkcji ${ }^{3}$.

Tabela 1. Produkcja wydawnicza Poznania na tle ziem dawnej Polski

\begin{tabular}{|c|c|c|}
\hline Dekada & $\begin{array}{c}\text { Liczba tytułów Poznania/liczba } \\
\text { tytułów ogółem }\end{array}$ & $\begin{array}{c}\text { Udział Poznania w produkcji ogółem } \\
\text { (w \%) }\end{array}$ \\
\hline $1815-1824$ & $197 / 4662^{*}$ & 4,2 \\
\hline $1825-1834$ & $\mathbf{2 4 6 / 5 3 8 5}$ & 4,6 \\
\hline $1835-1844$ & $\mathbf{6 3 3 / 6} 727$ & 9,4 \\
\hline $1845-1854$ & $\mathbf{1 0 6 6 / 8 5 7 9}$ & 12,4 \\
\hline $1855-1864$ & $\mathbf{1 0 8 0 / 1 1 9 1 7}$ & 9,1 \\
\hline $1865-1874$ & $\mathbf{1 3 1 3 / 1 2 8 7 2}$ & 10,2 \\
\hline $1875-1884$ & $\mathbf{1 5 6 3 / 1 8 4 2 0}$ & 8,3 \\
\hline $1885-1894$ & $\mathbf{1 9 7 3 / 2 0 6 4 0}$ & 8,5 \\
\hline $1895-1904$ & $\mathbf{1 5 9 9 / 2 0 6 9 0}$ & 7,7 \\
\hline $1905-1914$ & $\mathbf{2 0 3 1 / 3 0 2 8 7}$ & 6,7 \\
\hline
\end{tabular}

* Pierwsza liczba wskazuje tytuły wydane w Poznaniu, druga po ukośniku liczbę tytułów zarejestrowanych przez M. Czarnowską dla ziem całej Polski.

Źródło: własna baza danych dotyczących druków z lat 1801-1914; M. Czarnowska, Ilościowy rozwój polskiego ruchu wydawniczego 1501-1965, Warszawa 1967.

2 A. Jazdon, Wydawcy poznańscy 1815-1914, Poznań 2012, s. 192.

3 Tamże, s. 193. 
Struktura produkcji książek z interesującego nas zakresu w latach 18151914 przedstawiała się następująco ${ }^{4}$ :

- literatura piękna - 14,03\%,

- literatura religijna - 13,90\%,

- literatura historyczna i biografie - 12,59\%,

- literatura społeczno-polityczna - 7,45\%,

- księgoznawstwo - 6,29\%,

- muzyka-6,00\%,

- druki urzędowe, administracyjne, informacyjne - 5,52\%,

- nauka o literaturze, językoznawstwo - 5,20\%,

- medycyna - 3,44\%,

- pedagogika, szkolnictwo - 3,37\%,

- sztuka, kultura - 2,79\%,

- rolnictwo, gospodarstwo wiejskie, ogrodnictwo - 2,71\%,

- geografia, turystyka, krajoznawstwo - 2,68\%,

- ekonomia, finanse, handel, rzemiosło - 1,88\%,

- prawo - 1,83\%,

- filozofia, etyka, psychologia - 1,59\%,

- piśmiennictwo matematyczno-przyrodnicze - 1,33\%,

- dzieła ogólne - 1,33\%,

- technika, przemysł - 1,11\%,

- pozostałe $-1,26 \%$.

Spojrzenie na powyższą strukturę pokazuje, że książka szkolna nie zajmowała ważnej pozycji w miejscowej produkcji wydawniczej. Raz jeszcze wskazać trzeba na pewną trudność w jednoznacznym przypisywaniu danej pozycji do określonego działu. Jako przykład służą książki z działu literatury religijnej, wśród których znaleźć można różnego rodzaju dzieje starego czy nowego przymierza (m.in. mającą kilkanaście wydań Krótką historię Kościoła Świętego Katolickiego ks. Jana Delerta). Wiele spośród nich ma np. charakter książek katechizmowych, a więc o dydaktycznym przeznaczeniu. Podobnie w dziale grupującym tytuły z zakresu historii literatury znajdujemy opracowania dziejów literatury polskiej, a w dziale książek historycznych opisanie dziejów Polski, które też nie były z założenia podręcznikami. Bez wątpienia książki te mogły być i były wykorzystywane zwłaszcza w nauce domowej, służyły zdobywaniu i ugruntowaniu wiedzy $z$ tego zakresu. Nie były jednak w żaden sposób, poprzez podtytuł czy wyraźne wskazanie we wstępie, przeznaczone do wykorzystania w dydaktyce szkolnej. Więcej, nie mogły mieć takiego przeznaczenia z uwagi na obowiązujące przepisy, ale jako takie były używane w szkołach niedzielnych, na pensjach czy w nauce domowej. Dodać należy, że pewne opracowania, pomimo że przygotowywane przez pedagogów z zachowaniem ówczesnych wymagań metodologicznych i dydaktycznych, nie zyskiwały jednak zgody na ich wprowadzenie do użytku szkolnego. Stwierdza ten fakt Lech Słowiński, omawiając podręczniki przygotowane przez Józefa Franciszka Królikowskiego, pisząc równocześnie, że nastąpiło to,

4 Tamże, s. 222. 
mimo że nie było w tym czasie opracowań lepszych niż te jego autorstwa ${ }^{5}$. Podobnie w relacji o książce Edwarda Dembowskiego Rys dziejów piśmiennictwa polskiego stwierdza, że z racji na zapatrywania polityczne i filozoficzne autora książka ta nie miała dostępu do ówczesnych szkół średnich, ale pomyślana była jako popularny podręcznik literatury polskiej, na co wskazuje zarówno jej układ, jak i sposób ujęcia materiału historycznoliterackiego ${ }^{6}$. Używane w pensjach, na stancjach, w nauce domowej książki kształtowały wyobrażenia, poglądy, ideały życiowe, gusta literackie ich czytelników. Podobnie było przecież kilka lat później, gdy podręczniki literatury polskiej braci Antoniego i Jana Poplińskich, mające doniosłe znaczenie dydaktyczne, społeczne i narodowe i odgrywające dużą rolę w nauczaniu szkolnym,weszły wpierw do prywatnych szkół, następnie do nauczania domowego, gdy język polski został ze szkół zaboru pruskiego usunięty ${ }^{7}$. Przykłady te pokazują pewną trudność dokładnego i precyzyjnego określenia, które z opracowań należy zaliczyć do literatury szkolnej w rozumieniu podręcznikowej, które do szerzej rozumianej literatury pedagogicznej, które w ostateczności w tym omówieniu pominąć.

Dla porównania podajmy, że Marianna Mlekicka w badaniach dotyczących Warszawy z tych samych lat wyliczyła, że podręczniki szkolne i do nauki języków obcych stanowiły $3,4 \%$ całej produkcji ${ }^{8}$, co pozwalałoby powiedzieć o nadzwyczajnej wręcz zgodności wyników. W badaniach dla Poznania w wyznaczonym dziale nie ograniczono się jednak tylko do podręczników. Co więcej, część podręczników statystycznie została ujęta w innych działach tematycznych. Gdy zsumujemy te cząstkowe dane, uzyskujemy dla Poznania wynik na poziomie 5,1\%, w tym typowych podręczników do użytku szkolnego w całej produkcji odnotowujemy $2,5 \%$. Należy także dodać, że udział tej literatury w produkcji wydawniczej w ciągu badanego wieku nie był równomierny. Największy odsetek stanowiły one w latach 1840-18609. Było to wynikiem kumulacji kilku zapewne czynników: pewnego rozluźnienia politycznego, względnej swobody w posługiwaniu się językiem polskim w nauczaniu szkolnym, dużej aktywności społecznej przejawiającej się także w takich działaniach, jak np. założenie Towarzystwa Pedagogicznego, liczebnego wzrostu i aktywizacji miejscowych wydawców. Wspomniany niezbyt wysoki udział literatury z tego zakresu w produkcji globalnej wiązać jednak należy także z ogólną sytuacją społeczno-polityczną, w tym z warunkami rozwoju szkolnictwa. Są one omówione w literaturze przedmiotu, więc tylko krótko przypomnieć trzeba, że zaborca, dążąc do pełnej asymilacji Księstwa z pozostałymi prowincjami, starał się zrównać je z nimi pod względami prawno-administracyjnymi, nie dając namiastek autonomii. Równocześnie Poznań był najdalej na wschód wysuniętym miastem, któremu przypisywano cele militarne (Festung Posen), a nie

5 L. Słowiński, Nauka literatury polskiej w szkole średniej w latach 1895-1914, Warszawa 1976, s. 89.

6 Tamże, s. 113.

7 Tamże, s. 94-95; S. Truchim, Historia..., t. 2, s. 107.

8 M. Mlekicka, Wydawcy książek w Warszawie w okresie zaborów, Warszawa 1987, s. 107.

9 Por. A. Jazdon, Podręczniki w ofercie wydawców poznańskich (1831-1862), „Kronika Miasta Poznania" 2001, nr 4, s. 179-190. 
naukowe, kulturalne czy nawet gospodarcze. Stąd niski odsetek inteligencji wśród mieszkańców, duża grupa napływowych urzędników niemieckich (administracji cywilnej i wojskowej), brak szkolnictwa wyższego, brak zgody na rozwój wielu inicjatyw społecznych albo blokowanie udziału w nich pewnych grup zawodowych. Tak np. właśnie nauczyciele mieli formalny zakaz należenia do Poznańskiego Towarzystwa Przyjaciół Nauk, co uniemożliwiało im działania w jego strukturach, pozbawiało motywacji do rozwoju. Stąd „ucieczka” wielu dobrych nauczycieli pragnących rozwijać się naukowo do innych ośrodków i obejmowanie tam posad na uczelniach wyższych (mowa tu np. o Antonim Małeckim, Józefie Muczkowskim, Władysławie Nehringu, Kajetanie Trojańskim). Na ich miejsce zatrudniano nauczycieli niemieckich.

Mimo że państwo deklarowało walkę z analfabetyzmem, nie zakładano, że poziom nauczania w miejscowych szkołach powinien być wysoki. Wszyscy mieli posiąść umiejętność pisania i czytania, ale na poziomie niezbędnym do sprawnego funkcjonowania, czytania i zrozumienia wytycznych, zaleceń, instrukcji itp., po to, aby żyć w zgodzie z przepisami prawa. System szkół średnich w całym Księstwie nie był rozbudowany, programowo zróżnicowany. $Z$ biegiem lat sytuacja pogarszała się, doprowadzając w ostateczności do strajku dzieci wrześnieńskich. W szkołach średnich do 1846 roku naukę w klasach początkowych prowadzono w języku polskim, zwiększając stopniowo zakres nauczania w języku niemieckim, tak aby w dwóch ostatnich klasach mogła ona odbywać się już wyłącznie po niemiecku. Po 1846 roku nastąpiły dalsze zmiany na niekorzyść języka polskiego ${ }^{10}$, a po roku 1871 nastąpił zasadniczy zwrot w polityce Prus wobec Polaków, czego wyrazem w odniesieniu do szkolnictwa było wprowadzenie języka niemieckiego jako wykładowego. Język polski ograniczono jako przedmiot nauczania. Od połowy lat 70. do lat 90. nauka języka polskiego w szkołach średnich czy seminariach nauczycielskich była przedmiotem nadobowiązkowym. Później język polski usunięto całkowicie z nauczania, a także jako język egzaminów wstępnych czy maturalnych. W szkołach elementarnych eliminowano z nauki języka ojczystego gramatykę i lektury, zwracając uwagę jedynie na ćwiczenia w mówieniu. Skutkowało to też wprowadzaniem jako obowiązujących podręczników niemieckich, niekoniecznie wydawanych przez miejscowych wydawców, czy w odniesieniu do wspomnianego języka ojczystego prostych rozmówek polsko-niemieckich i łatwych czytanek do tłumaczenia. Zabraniano rozmów po polsku na terenie szkół, karano za czytanie prasy polskiej, wypożyczanie książek polskich, także z bibliotek szkolnych. Obostrzenia dotyczyły szkół wszystkich typów. Tak np. w prywatnej szkole polskiej dla dziewcząt Anastazji Warnke, sprawozdanie wizytacyjne z 1875 roku zwracało uwagę, iż wprowadzenie języka niemieckiego jako wykładowego nie zostało zrealizowane. Po tym roku uczono w niej języka polskiego po dwie godziny, wykorzystując czytanki Poplińskiego, gramatyki T. Radońskiej, Naukę poezji H. Cegielskiego, Kurs literatury polskiej W. Nehringa, a po 1899 roku język polski pozostał tylko w nauce religii w najniższych klasach ${ }^{11}$.

10 S. Truchim, Historia..., t. 1, s. 114.

11 Tenże, Historia..., t. 2, s. 107. 
Mówiąc o literaturze pedagogicznej w tym ujęciu statystycznym, wskazać należy jeszcze na dwie sprawy. Ogólnie można stwierdzić, że rejestracja produkcji wydawniczej dla XIX wieku nie jest kompletna, choć jej ocena nie na podstawie spisów bibliograficznych, ale prowadzonych zestawień daje pełniejsze wyniki. Jednakże w przypadku książki szkolnej, podręczników mieliśmy szczególnie często do czynienia ze zjawiskiem kolejnych wydań. Było to spowodowane szybkim ich zaczytywaniem ze względu chociażby na to, że publikowano je w nie najwyższym standardzie wydawniczym (np. słaby papier, broszurowa oprawa), więc były podatne na szybkie zużycie. Do tego dochodziło niedbałe użytkowanie przez młodego czytelnika, przechowywanie nie zawsze w najlepszych warunkach, szybkie przekazywanie kolejnym szkolnym rocznikom. Często książki wydawane były nakładem własnym autorów, którzy pod wypływem doświadczeń pedagogicznych wprowadzali zmiany i poprawki, wypuszczając kolejne edycje. Należy dodać, że autorzy byli także zainteresowani tym, aby dzieci książki posiadały, dlatego też wydawano je tanio, albo często dodrukowywano w ramach niezmienionych wydań. Nie zawsze można odróżnić, czy dany egzemplarz to dodruk czy jednak kolejne wydanie. To sprawiało, że właśnie w zakresie książki szkolnej odnotować trzeba takie trudne do zweryfikowania przypadki, jak Karola Kasińskiego Książki do początkowego czytania dla szkół polskich jako też i niemieckich..., której wydanie z 1878 roku zostało oznaczono jako... 67, kolejne odnotowane z 1880 jako 69, edycja z 1881 jako 93, a z 1883 już jako 116! Nawet jeśli prawdziwość tych wskazań nie zostanie podważona, to należy uświadomić sobie, że obecnie rejestruje się i można z autopsji poznać... znikomy odsetek wydań tego podręcznika!

Drugi wniosek wypływa z próby odpowiedzi na pytanie - wykraczające poza sformułowany temat tego artykułu - czy w przypadku książki szkolnej możemy mówić o identycznym, jak to widać w badaniach kompleksowych, udziale ośrodków prowincjonalnych w produkcji globalnej. W tym wypadku możemy odnieść to tylko do W. Ks. Poznańskiego, ponieważ M. Mlekicka nie prowadziła badań dla Królestwa Polskiego. Stwierdzić należy, że w przypadku Księstwa, Poznań jako jego stolica był najbardziej aktywnym ośrodkiem wydawniczym, poza nim ukazało się tylko $20 \%$ zarejestrowanej produkcji ${ }^{12}$. W zakresie książki pedagogicznej wyliczyć trzeba, iż ośrodki prowincjonalne publikowały jej więcej, osiągając poziom $27 \%$. Wytłumaczenie jest naturalnie proste. W takich ośrodkach, jak Leszno, Gniezno, a jeszcze bardziej Trzemeszno, Wschowa, Śrem - a więc mniejszych i pozbawionych innych niż szkoły kulturotwórczych instytucji, pozbawionych ogniw administracji czy później większych zakładów pracy - właśnie istnienie szkoły było siłą w sposób znaczący „napędzającą” działalność wydawniczą i drukarską. Istnienie szkoły oznaczało funkcjonowanie w danym ośrodku grupy wykształconych osób, z których część miała ambicje samodzielnego przygotowywania różnego rodzaju pomocy dydaktycznych. Często w tych ośrodkach wydawano samodzielnie książki zalecone dla danego typu szkoły, nie sprowadzając poprzednich wydań z Poznania, lecz uzgadniając (lub nie!) z autorem warunki lokalnej edycji. Dziś

12 A. Jazdon, Przeobrażenia wielkopolskiej oferty wydawniczej lat 1801-1918, „Kronika Wielkopolski" 1990, nr 4, s. 9. 
może trudniej to sobie wyobrazić, ale wówczas ten sam autor niezmienione dzieło wydawał w dwóch różnych ośrodkach, jeśli księgarz-nakładca widział szanse jego lokalnego zbytu. W tym momencie dodać można na marginesie informacje o charakterystycznych dodatkach do corocznych sprawozdań miejscowych szkół średnich. Zawierały one opracowania naukowe nauczycieli tychże szkół. Także w tym wypadku istnieje problem z ich rejestracją, gdyż nie wszystkie sprawozdania dotrwały w komplecie do naszych czasów, ale także dlatego, że część tych dodatków nie była ujawniana w opisach sprawozdań, stanowiąc ich integralną część. W niektórych jednak przypadkach można powiedzieć, że wydawane były oddzielnie, z samodzielną paginacją i broszurową oprawą.

Należy wskazać, iż przywołany powyżej argument częstego wydawania podręczników miejscowych autorów z uwagi na lokalną dogodność, z innych punktów widzenia nie zawsze był decydujący. O ile np. wiadomo, że pewne opracowania Tomasza Szumskiego, Józefa F. Królikowskiego, Hipolita Cegielskiego, Józefa Rymarkiewicza, Władysława Nehringa, Antoniego i Jana Poplińskich używane były poza terenami Wielkopolski ${ }^{13}$, to $\mathrm{np}$. w Poznaniu jednym z częściej wydawanych był Rys dziejów piśmiennictwa polskiego Lesława Łukaszewicza (wydania poznańskie z lat 1859, 1860, 1864 i 1866). Ten problem wykorzystywania podręczników na ziemiach innych zaborów, o specyficznych oczekiwaniach, wymagający szczegółowego opracowania, nie pozostawał także bez wpływu na rozwój własnego środowiska wydawniczego.

Ostatnie porównanie w tej części dotyczy udziału książki obcojęzycznej w produkcji globalnej. O ile dla Poznania badanego okresu wyliczono, że książka obcojęzyczna stanowiła $22 \%$, to w interesującym nas przypadku książki szkolnej jej odsetek wynosi blisko 30\%. Przeważa w tym książka niemieckojęzyczna, choć nie brakuje też wydań w języku łacińskim. Jest to zrozumiałe, gdyż książki niemieckojęzyczne dla innych celów i potrzeb łatwo było do Poznania sprowadzić $z$ terenu Niemiec, co nie generowało potrzeby wyłącznej ich produkcji na miejscu. W przypadku książki szkolnej, pisanej często przez miejscowych nauczycieli, niezbędnej do realizacji procesu dydaktycznego miejscowych szkół w dużej liczbie egzemplarzy, sensowniej było wydawać ją na miejscu. Podręczniki łacińskojęzyczne służyły nauce tegoż języka.

Odpowiedź na pytanie o to, kto literaturę z interesującego nas zakresu wydawał, jaki był jej udział w dorobku danej oficyny, należy ponownie rozpocząć od nakreślenia szerszej perspektywy, ukazującej, iż w badanym okresie w Poznaniu grupa zawodowych pracowników książki (księgarzy, drukarzy, nakładców) liczyła przeszło 220 podmiotów, z których 87 prowadziło działalność wydawniczą. Od razu należy powiedzieć, że wśród nich nie ma wydawcy, który świadomie określiłby, że jego specjalizacją jest literatura szkolna, pedagogiczna. To dostrzec można dopiero w okresie międzywojennym ${ }^{14}$. Jednakże zauważyć trzeba także

${ }_{13}$ Zob. zestawienie ważniejszych podręczników z uwzględnieniem ich zasięgu terytorialnego, L. Słowiński, Nauka literatury..., s. 270-277.

${ }^{14}$ Działały wówczas takie księgarnie asortymentowe i wydawniczo-nakładcze, jak: Centrala Podręczników, Księgarnia Nauczycielska, Księgarnia Spółki Pedagogicznej, Księgarnia Stowarzyszeń 
to, że blisko połowa z nich (bo 40) miała w swoim dorobku wydawniczym literaturę z tego zakresu. Oczywiście, każda oficyna angażowała się w jej produkcję w innym stopniu, ale świadczy to także o tym, że wydawaniem tej literatury zajmowano się chętnie. Odpowiedź na pytanie o przyczyny takiego stanu rzeczy wydaje się dość prosta i nawiązuje do wcześniej wymienionych już czynników: łatwości pozyskania autora miejscowego, łatwości zbytu wynikającej z faktu istnienia szkoły. Dochodziły do tego w niektórych przypadkach szczególne uzasadnienia. Tak np. księgarze i wydawcy - Tomasz Szumski i Antoni Popliński byli nauczycielami gimnazjalnymi, więc ich świadomość potrzeb w tym zakresie była szczególnie wysoka. Należy jednak powiedzieć, że powyższa rejestracja, w związku z faktem podejmowania się funkcji wydawców przez często małe i sporadycznie w tej roli występujące podmioty, może być niepełna. Nie wszystkie książki poznano z autopsji i być może w stosunkowo dużej liczbie (przeszło 30) przypadków, dla których nawet hipotetycznie nie zdołano przypisać wydawcy, znajdują się także inni, wcześniej nieodnotowani wydawcy. Duża była także w tej grupie liczba wydań zrealizowanych nakładem autorów, bo tytułów takich zarejestrowano przeszło 60. Spośród wydawców niezawodowych najliczniejszą grupę druków przypisać można miejscowej administracji i szkołom (blisko 50). W tej grupie aktywne były także redakcje czasopism (9) oraz miejscowe towarzystwa. Powyższe zestawienie pokazuje, że faktycznie publikowaniem książek szkolnych i dotyczących szkolnictwa zajmowała się, z różnych pobudek, bardzo zróżnicowana grupa podmiotów.

Jako najaktywniejszego na tej niwie spośród wydawców zawodowych wymienić należy Antoniego Poplińskiego. Jeszcze jako czynny nauczyciel, wspólnie z Józefem Łukszewiczem, w roku 1841 założyli Księgarnię Nową. Od momentu przejścia na emeryturę w 1852 roku firmę prowadził już samodzielnie, zgodnie z przyjętą specjalnością, jaką stanowiła literatura religijno-moralna i historyczna oraz piękna i - w mniejszym wymiarze - pozycje z zakresu nauk matematyczno-przyrodniczych. Jej staraniem światło dzienne do roku 1868 ujrzało 150 tytułów, z których 41 (czyli przeszło 27\%) stanowiły podręczniki szkolne. Nie było drugiego wydawcy, w przypadku którego dostrzec można byłoby podobne proporcje w strukturze oferty wydawniczej, co pozwala nazwać go mianem czołowego wydawcy w tym zakresie, nie tylko w Poznaniu, ale i w Wielkopolsce ${ }^{15}$. Znaczną ich część stanowiły nakłady podręczników przygotowanych przez Poplińskiego, a także Łukaszewicza. Dodać należy, że kolejnych 20 propozycji wydawniczych należy do nurtu szeroko ujmowanej literatury pedagogicznej.

W bardzo bogatym dorobku wydawniczym Jana Konstantego Żupańskiego, wydawcy m.in. opracowań Hipolita Cegielskiego, Ewarysta Estkowskiego, literatura pedagogiczna stanowiła blisko 80 pozycji. Na jego ofertę typowych podręczników składa się głównie kilka wydań prac wspomnianego Hipolita Cegielskiego (Gramatyka języka greckiego..., 1843, 1862; Nauka poezji..., wyd. 1-5 w latach 1845-1879; pojedyncze wydania Teoryi poezji..., 1869 oraz O słowie polskim...,

Nauczycieli Polskich, Księgarnia Szkolna, Przyjaciel Szkoły. Zob.: P. Nowak, Poznań jako ośrodek wydawniczy w dwudziestoleciu 1919-1939, Poznań 1997.

15 A. Jazdon, Wydawcy..., s. 65. 
1852), co pokazuje także, że często liczba wydań przypisanych jednemu wydawcy wynika z liczby wznowień jednego, cieszącego się popularnością, tytułu. Żupański w oczach współczesnych sobie, jak i w dzisiejszej ocenie, uznawany jest za najwybitniejszego wydawcę poznańskiego XIX wieku, świadomie kształtującego swoją politykę wydawniczą. W wielu ocenach bogatej działalności wydawniczej Żupańskiego podkreśla się zawsze jego patriotyzm i przywiązanie do sprawy polskiej, znajdujące odzwierciedlenie zarówno w doborze tytułów, jak i autorów, a poprzez to wspieranie rodzimych twórców. Był jednak przede wszystkim wydawcą literatury naukowej oraz pięknej. To człowiek bardzo zaangażowany w życie społeczne Wielkopolski, co zaowocowało tym, że poza wspomnianymi podręcznikami wydawał literaturę poświęconą sprawom oświaty, wychowania. Edycje zaspokajające potrzeby szkolne, oświatowe, wychowawcze zajęły w całej jego produkcji mniej niż 10\%. Z uwagi jednak na rangę wydawcy, były one zawsze oczekiwane i przyjmowane z najwyższa uwagą ${ }^{16}$.

Niemało tytułów (bo 23) zarejestrowano dla Księgarni Św. Wojciecha (KŚW), tego najbardziej aktywnego - z punktu widzenia średniej rocznej produkcji wydawniczej - edytora poznańskiego. Przypomnieć należy jednak, że w badaniach ujęto tylko pierwsze dwudziestolecie funkcjonowania oficyny. Zarejestrowane tytuły w większości należały do opracowań omawiających problematykę oświaty, wychowania, kształcenia, a nie były typowymi podręcznikami, których właściwie w tym okresie KŚW nie wydawała. Zgodne to było z założeniem programowym wydawnictwa, które służyć chciało szerzeniu oświaty, kultury, wzorców postaw społecznych, politycznych opartych na nauce Kościoła.

Niewiele niższy poziom pod względem ilościowym zajmuje książka pedagogiczna w ofertach: Ernsta Mittlera, Ludwika Merzbacha oraz Drukarni W. Deckera. W tym ostatnim przypadku niestety nie można stwierdzić, na ile jej właściciele samorzutnie podejmowali inicjatywy wydawnicze, a na ile realizowali tylko polecenia administracji. Była to drukarnia niemiecka, działająca w ścisłej symbiozie $z$ władzą, realizująca na jej zlecenie druk wielu publikacji także z innych dziedzin. Można więc $z$ dużym prawdopodobieństwem orzec, że i w tym przypadku inicjatywa była odgórna.

U wymienionego w grupie aktywnych wydawców Ernsta Mittlera literatura pedagogiczna stanowiła przeszło 15\%, co lokuje go wśród edytorów przywiązujących do niej duże znaczenie. Podobnie można powiedzieć o Karolu Reyznerze (12\% - w dość skromnej, bo liczącej ogólnie 150 tytułów produkcji) czy Josephie Jolowiczu (11\%). Mittler, charakterystycznie dla siebie, wydawał tak podręczniki niemieckie, jak i polskie (np. Tomasza Szumskiego czy Jana Rymarkiewicza), zaspokajając potrzeby różnych grup społecznych w rozmaitych zakresach dziedzinowych, co wynikało z jego ekonomicznego podejścia do prowadzonej działalności ${ }^{17}$. Inaczej odczytywać należy w tym zakresie działania Reyznera, koncentrującego się na publikowaniu książek elementarnych. W tym wypadku zauważyć trzeba jednak zgodność z przyświecającymi mu ogólnymi założeniami

${ }_{16}$ Por. M. Foć, M. Romanowska, Jan Konstanty Żupański. Życie i dzieło, Poznań 1996.

17 A. Jazdon, Wydawcy..., s. 42. 
kierowania swej produkcji, taniej, popularnej, o niewysokim standardzie edytorskim, do biedniejszych, mniej wykształconych warstw odbiorców ${ }^{18}$. Zaskakująco rzadko angażowali się w wydawanie tej literatury tak znani wydawcy, jak Napoleon Kamieński, Leitgeberowie czy - wspomniany poprzednio - Ludwik Merzbach. W przypadku tego ostatniego wydawcy, mimo iż zarejestrowano niemało, bo 24 publikacje, to stanowią one tylko ok. $5 \%$ całej jego produkcj! Wszystkie te przypadki potwierdzają tezę, że brakowało w Poznaniu w XIX wieku grupy wydawców w sposób świadomy, planowy ukierunkowujących swoją ofertę na zaspokajanie potrzeb czytelników w omawianym zakresie, a podejmowało się tej produkcji, z różnych pobudek, grono różnorodnych edytorów. Niestety, w dość znacznej liczbie przypadków, fakt wydania tak niewielu tytułów świadczyć może o dużej przypadkowości w podejmowaniu tych inicjatyw wydawniczych. Należy więc założyć, że zasadniczo inicjatywa nie leżała po stronie wydawców, lecz samych autorów, nauczycieli i wynikała z innych czynników zewnętrznych - w tym także tych o podłożu ekonomicznym. Stefan Truchim wskazywał, że szczególnie w pierwszych dziesięcioleciach XIX wieku, przede wszystkim w szkołach wiejskich, brak było jednolitych podręczników, uczono z różnych elementarzy, modlitewników, czasem korzystano tylko ze ściennych tablic do nauki czytania ${ }^{19}$. $Z$ biegiem lat, poczynając od szkół wyższego poziomu, schodząc na niższe poziomy nauczania, problem ten urzędowo regulowano, co jednak wpływało na ograniczanie roli oddolnych inicjatyw wydawniczych.

Można stwierdzić, że w grupie typowych podręczników szkolnych, poza paroma wymienionymi tytułami, miejscowi wydawcy nie opublikowali pozycji o wyjątkowym znaczeniu, wprowadzających nowatorskie rozwiązania metodyczne. Podobnie ocenić można grupę publikacji poświęconych organizacji szkół, ich funkcjonowaniu. Miały one charakter publikacji miejscowych, o ograniczonym zasięgu i zakresie terytorialnym oraz czasowym. Inaczej należy ocenić kilkanaście przynajmniej edycji poświęconych ogólnie wychowaniu, kształceniu, możliwych do wykorzystania w nauce domowej, w działaniach wychowawczych realizowanych przez dom, Kościół katolicki i jego instytucje czy organizacje i towarzystwa społeczne. Wymienić wśród nich można takie edycje, jak: Wieczory pod lipą Lucjana Siemieńskiego (Kamieński 1845, 1847), Legendy historyczne Zofii Węgierskiej (Żupański 1852, 1863), Zbiorek rzeczy swojskich ku nauce i rozrywce młodzieży Ewerysta Estkowskiego (Żupański 1859).

Ważnymi edycjami naukowymi, które służyć mogły „wyższemu kształceniu” przygotowanych już odbiorców, były m.in. Maurycego Mochnackiego O literaturze polskiej w XIX wieku (Stefański 1845), Adama Mickiewicza Rzecz o literaturze słowiańskiej wykładana w Kolegium Francuskim (Stefański 1850-1851), pionierskie Studia o literaturze ludowej ze stanowiska historycznej i naukowej krytyki Ryszarda Berwińskiego (Żupański 1854), Kazimierza Jarochowskiego Literatura poznańska w pierwszej połowie bieżącego stulecia (Żupański 1880, 1884) czy

18 Por. tenże, Karol Reyzner (1803-1887) - wydawca, księgarz i drukarz poznański, „Biblioteka” 2009, nr 13 (22), s. 55-76.

19 S. Truchim, Historia..., t. 1, s. 134. 
tegoż liczne edycje dzieł Joachima Lelewela. Nade wszystko wymienić należy: Uwagi nad wychowaniem teraźniejszym Johanna Samuela Kaulfussa (Decker 1823), wśród wielu różnych edycji dzieł Bronisława Trentowskiego Chowannę, czyli system pedagogiki narodowej (Popliński 1842, 1845-1846), przedruk Grzegorza Piramowicza Powinności nauczyciela (Stefański 1849), Pisma pedagogiczne E. Estkowskiego (Żupański 1863), Jędrzeja Śniadeckiego O fizycznym wychowaniu dzieci (L. Rzepecki 1867), z uwagi na pozycję społeczną autora Mowę o potrzebach i położeniu szkół naszych Floriana Stablewskiego (J. Leitgeber 1878) czy Wojciecha Trąmpczyńskiego O szkołach ludowych i prywatnym nauczaniu (nakł. autora, 1913).

Już wcześniej w tej analizie próbowano odpowiedzieć na pytanie, kto był inicjatorem opracowywania poszczególnych podręczników. Z jednej strony należy stwierdzić, że byli to nauczyciele, znający wymagania szkolne, potrzeby w tym zakresie, z drugiej była to także władza szkolna. Nauczyciel musiał jednak liczyć się z tym, że jego opracowanie wymagało zaaprobowania do użytku szkolnego. W przeciwnym wypadku wypadało z użycia, a władza nadrzędna wprowadzała podręcznik uznany za lepszy czy z punktu widzenia politycznego, społecznego właściwszy. Tak np. po zmianie kursu politycznego w latach 70. XIX wieku zadecydowano o wycofaniu podręczników Jana Rymarkiewicza, przez lata uznawanych za dobre i aprobowanych do użytku szkolnego. Nie pomogły zapewnienia autora i wydawcy, że kolejne wydanie dostosują do oczekiwań. Urzędowo zlecono opracowanie nowych podręczników Józefowi Molińskiemu i Sylwestrowi Spychałowiczowi ${ }^{20}$. Nie zawsze jednak powierzano ich przygotowywanie miejscowym autorom, co przyczyniałoby się do rozwoju miejscowego ruchu wydawniczego, czasem zalecano stosowanie wydań z terenu Niemiec. W latach 1840-1862, czyli w okresie pozornych ustępstw, np. w seminariach nauczycielskich, podstawowym podręcznikiem do nauki języka niemieckiego był podręcznik Kellnera i Heyse’go, do historii Rendschmidta, do fizyki Krügera Grundzüge der Physik ${ }^{21}$.

Władze kościelne, chcąc uzyskać odpowiedni do swych oczekiwań katechizm, także podejmowały różnorodne działania. $Z$ jednej strony było to dążenie do rzetelnej oceny nadsyłanych propozycji, z drugiej inicjowanie konkursów czy zlecanie konkretnym osobom zadania ich przygotowania. Wydawcy książek o tematyce religijnej, moralnej, starali się uzyskać imprimatur władzy kościelnej, co ułatwiało zbyt książek i „legalizowało” posługiwanie się nimi. W aktach archiwalnych odnaleźć można więc np. datowaną na 1857 rok ocenę rękopisu katechizmu Mały towarzysz autorstwa ks. Gawareckiego, który nie polecał konsystorzowi arcybiskupiemu jego aprobaty, stwierdzając: „Już dużo takich małych katechizmów wyszło, i trzeba powiedzieć, więcej niźli potrzeba"22. Władze kościelne, widząc sytuację, zleciły wówczas Janowi Respądkowi, proboszczowi ponieckiemu, napisanie katechizmu wzorcowego. Ten podjął się zadania, ubolewając, iż faktycznie te stosowane, oparte na różnych metodach wprowadziły w naucza-

20 L. Słowiński, Nauka literatury..., s. 130.

21 S. Truchim, Historia..., t. 1, s. 200.

22 AAP, rkps KA 9220. Cenzura ksiąg. List z 20.08.1857. 
niu religii zamęt i twierdził, że nie ma wśród istniejących takiego, który by można zastosować we wszystkich szkołach ${ }^{23}$. Ale fakt zlecenia osobie wybranej przez Arcybiskupa realizacji tego zadania nie oznaczał poprawy sytuacji. Oceniający ją bowiem kilka lat później recenzent „Tygodnika Poznańskiego” zauważał, iż zalała archidiecezję „moc przeobfita najróżnorodniejszych” opracowań, w wyniku czego „zamęt doszedł po szkołach naszych do tego stopnia”, iż każda nieomal szkoła jednej i tej samej parafii użytkowała inne opracowanie ${ }^{24}$.

Inaczej niż w zakresie podręczników wyglądała sprawa inicjatywy wydawniczej w odniesieniu do tych publikacji, które mogły być używane jako podręczniki w nauczaniu domowym czy służyć miały wychowaniu, kształceniu, podnoszeniu oświaty. Starały się na to wpływać zakładane towarzystwa. Bez wątpienia Poznańskie Towarzystwo Przyjaciół Nauk (1857) było towarzystwem najbardziej znanym i o największych osiągnięciach również na niwie wydawniczej, ale nie inicjowało wydawania podręczników, a i sprawy oświaty, wychowania stanowiły węższy zakres jego zainteresowań. Wiele lat wcześniej, bo w roku 1828, zawiązało się Towarzystwo Przyjaciół Rolnictwa, Przemysłu i Oświaty w Wielkim Księstwie Poznańskim, które dążąc do realizacji zadań związanych z ich rozwojem, zamierzało organizować konkursy i prowadzić działalność wydawniczą ${ }^{25}$. Nie uzyskało jednak aprobaty władz. Takie same założenia były często w latach następnych wymieniane w dokumentach innych organizacji i stowarzyszeń, co podkreśla uświadamianie sobie przez ich założycieli znaczenia słowa drukowanego w życiu społecznym.

Powstała w 1848 roku Liga Polska w swych założeniach organizacyjnych zapisała, iż realizować będzie swe cele przez wydawanie książek i czasopism, dla rozwijania oświaty narodowej ${ }^{26}$. Po niespełna dwóch latach jej działalność została zawieszona, zdążyła jednak rozpocząć publikowanie książek, zauważając, że istnieje „niedostatek książek stosownych” dla ludu, rodzący potrzebę wydania prac zróżnicowanych pod względem formy i zakresów tematycznych ${ }^{27}$. Powstałe w tym samym roku, z inicjatywy Ewarysta Estkowskiego i ks. Aleksego Prusinowskiego, Towarzystwo Pedagogiczne Polskie wskazało jako swe cele walkę o utrzymanie języka polskiego w szkołach elementarnych, troskę o poprawę bytu nauczycieli, dążenie do zrównania ich w prawach z urzędnikami państwowymi i szerzenie wiedzy pedagogicznej przez wydawanie odpowiednich poradników dydaktycznych, pism pedagogicznych i podręczników do szkół elementarnych ${ }^{28}$. Dla ich realizacji

${ }_{23}$ Por. J. Respądek, Katechizm rzymsko-katolicki dla szkół elementarnych i klas niższych gimnazjalnych, Poznań 1858, s. I-III.

24 „Przegląd Poznański” 1863, nr 9, s. 70-71.

25 Z. Skorupska, Towarzystwo Przyjaciół Rolnictwa, Przemysłu i Oświaty w Wielkim Księstwie Poznańskim, [w:] Słownik Polskich Towarzystw Naukowych, t. 2, cz. 2, red. nauk. B. Sordylowa, Warszawa 1994, s. 497-498.

26 J. Kozłowski, Wielkopolska pod zaborem pruskim w latach 1815-1918, Poznań 2006, s. $155-157$.

27 „Gazeta Polska” 1849, nr 140, s. 577-578.

28 S. Truchim, Pierwsze Towarzystwo Pedagogiczne w Polsce 1848-1853. Z początków zawodowego ruchu nauczycielskiego, Warszawa 1958, s. 146. 
wybrano pięcioosobowy Komitet Redakcyjny ${ }^{29}$, co stanowiło realizację projektu zgłoszonego kilka lat wcześniej przez Karola Libelta ${ }^{30}$. W 1849 roku powołano oddzielny komitet dla redagowania czasopisma pedagogicznego „Szkoła Polska” oraz komisję dla opracowania elementarza, która jednak nie rozwinęła szerszej działalności ${ }^{31}$. Troszcząc się o właściwe wychowanie młodego pokolenia, w tym samym roku Towarzystwo poleciło W. Stefańskiemu przedrukować Powinności nauczyciela Grzegorza Piramowicza. Realizując natomiast zamysł przygotowania „książki początkowej do czytania”, spośród znanych sobie i poleconych nauczycieli wybrało Daniela Rakowicza i jemu powierzyło wykonanie tego zadania ${ }^{32}$. Wywiązał się z zadania na tyle dobrze, że pracę jego, pod tytułem Nauka czytania i pisania. Wypracowana z polecenia Towarzystwa Pedagogicznego w Poznaniu, wydano w 1850 roku, a już rok później wznowiono. Współzałożyciel i działacz Towarzystwa E. Estkowski, także pracami swego autorstwa przyczynił się do zapełniania luk na polu książki elementarnej.

O tym, że nie wszystkie inicjatywy w tym zakresie były realizowane, świadczy plan Franciszka Rakowicza, który w roku 1861 rzucił hasło powołania do życia Towarzystwa św. Wojciecha mającego: zakładać czytelnie, rozdawać tanie książki, sprzedawać takowe oraz inicjować i organizować wydania nowych dzieł dla ludu $^{33}$. Nie wystarczały same chęci i nawet najszczytniejsze zamierzenia, jeśli brakowało szerszego zaplecza, tak intelektualnego, jak i organizacyjno-finansowego. Należy jednak przypomnieć, że wzywanie do powoływania stowarzyszeń dla wydawania tanich książek dla ludu było w tych latach dość powszechne, bo podobne hasła, wskazujące powodzenie takich przedsiębiorstw czeskich i ruskich $^{34}$, pojawiały się np. także w Galicji. Warto w tym kontekście przypomnieć niepodjętą myśl J. I. Kraszewskiego, aby zjednoczyć wysiłki poznańskie i krakowskie dla wspólnego wydawania literatury dla ludu ${ }^{35}$.

Odpowiedzią Polaków na politykę okresu O. Bismarcka było utworzenie najpierw w roku 1872 Towarzystwa Oświaty Ludowej, a po jego sądowym zawieszeniu Towarzystwa Czytelni Ludowych (TCL) w roku $1880^{36}$. Ich głównym celem było propagowanie polskiej prasy i książek i organizowanie biblioteczek ludowych mających zapewnić dostęp do literatury pięknej, opracowań historycznych, ale

\footnotetext{
29 „Kościół i Szkoła” 1848, nr 9, s. 556-559.

30 Por. J. Data, Tendencje pozytywistyczne w czasopiśmiennictwie wielkopolskim $w$ latach 1848-1870, Warszawa-Poznań 1975, s. 105.

31 B. Krajewska-Tatarkowska, Polskie Towarzystwo Pedagogiczne w Poznaniu, [w:] Słownik Polskich Towarzystw Naukowych, t. 2, cz. 3, red. nauk. B. Sordylowa, Warszawa 2001, s. 64.

32 „Przegląd Poznański”1848, t. 4, s. 663.

${ }_{33}$ Zob. F. Rakowicz, Towarzystwo św. Wojciecha duchowy Pomnik Tysiącletniej Rocznicy, Poznań 1861.

${ }^{34}$ Por. J. Bujak, Informacja o książce i prasie w tygodnikach galicyjskich 1772-1900, Kraków 1989, s. 64.

35 J. I. Kraszewski, Rachunki. Z roku 1866, Poznań 1867, s. 249-250.

36 Zob. B. Zakrzewska-Nikiporczyk, Towarzystwo Oświaty Ludowej, [w:] Słownik Polskich Towarzystw Naukowych, t. 2, cz. 2, red. nauk. B. Sordylowa, Warszawa 1994, s. 476-478; W. Jakóbczyk, Towarzystwo Czytelni Ludowych, [w:] Słownik Polskich Towarzystw Naukowych, t. 2, cz. 1, red. nauk. B. Sordylowa, Wrocław 1990, s. 480.
} 
i popularnych z różnych dziedzin życia: kulturalnego, społecznego, politycznego i gospodarczego. Towarzystwa te korzystały głównie z nakładów miejscowych wydawców, inspirując, zachęcając ich do publikowania literatury niezbędnej dla zakładanych bibliotek, co było już samo w sobie ważnym zadaniem, ale także same stawały się nakładcami. Szczególnie TCL było na tej niwie aktywne, stając się wydawcą 35 pozycji, wśród których odnajdujemy: ciąg wydawnictw stanowiących objaśnienia do przeźroczy z historii Polski lub literatury polskiej, elementarze, sporadycznie poradniki prawne oraz kilkanaście tytułów spisów książek polecanych - jako odpowiednie - dla bibliotek.

Niemałą rolę w rozwoju miejscowego ruchu wydawniczego, w inspirowaniu pewnych w tym zakresie zdarzeń, wskazywaniu dobrych i wartych powielania wzorców, jak i krytykowaniu złych edycji, odegrała miejscowa prasa i jej redakcje. Można jednak śmiało powiedzieć, że w zakresie pozycji podręcznikowych była ona - poza elementarzami - praktycznie zerowa. Częściej wskazywano na tytuły, które mogły służyć wychowaniu czy nauczaniu domowemu, podnoszeniu oświaty, choć w zasadzie przyznać trzeba, że z reguły wskazywano na typy książek, rodzaj ich opracowania, żądaną tematykę niż na konkretne dzieła. Dostrzegano konieczność podnoszenia poziomu nauczycieli, w tym m.in. poprzez wydawanie dla nich czasopism ${ }^{37}$. Niemałą rolę w tym dyskursie odegrali: Julia Wojkowska, Hieronim Feldmanowski, Karol Libelt ${ }^{38}$. Niektóre tylko tytuły poddawano szczegółowym recenzjom, choć w odniesieniu do podręczników nie czyniono tego zbyt często i systematycznie, a w odniesieniu do literatury pedagogiczno-oświatowej, wychowawczej nie częściej niż w stosunku do innych grup tematycznych. Recenzje nie wpływały w sposób widoczny na podejmowane działania wydawnicze, choć zdarzały się wśród recenzji podręczników i takie, jak ta po opublikowaniu przez Reyznera drugiego wydania Małej gramatyki języka polskiego, którą skwitowano stwierdzeniem: „w wydaniu tego dziełka autor najwięcej rozumu pokazał $w$ tem, że zataił nazwisko swoje" 39 . Nie przeszkodziło to jednak wydawcy opracowanie to wznowić jeszcze trzykrotnie!

Poza łamami czasopism, praktycznie przez większą część badanych lat nie publikowano broszur czy obszerniejszych książek poświęconych podręcznikom czy literaturze pedagogicznej, oświatowej. Tej ostatniej poświęcił uwagę Bernard Chrzanowski w broszurze $W$ sprawie wydawnictw ludowych, wydanej dopiero w 1911, w której mówił o funkcji wychowawczej, ale i kształcącej tego typu wydawnictw. W tym kontekście wskazać należy na opublikowany kilkanaście lat wcześniej List otwarty do społeczeństwa polskiego w sprawie naszych elementarzy autorstwa byłego nauczyciela kryjącego się pod inicjałami A. B. Ideę analizy podkreśla podtytuł, jakim autor ją poprzedził: Elementarze polskie jakiemi być powinny, a jakiemi są. Omówił szczegółowo wszystkie wydane w Wielkopolsce

37 Np. B., Słówko o potrzebie polskich pism pedagogicznych, „Oświata” 1865, z. 1, s. 34-36; Jedna z najgwałtowniejszych naszych potrzeb, „Tygodnik Poznański” 1863, nr 5, s. 33-34.

38 Szerzej poruszyłem ten problem w książce Wydawcy poznańscy..., s. 270-303. Tam też wskazana literatura omawiająca ten rozpoznany już dobrze problem.

39 „Orędownik Naukowy” 1844, nr 1, s. 87-88. 
na przestrzeni ostatnich trzech dziesięcioleci elementarze, starając się zbudować założenia elementarza idealnego. Tego typu opracowań zabrakło w XIX-wiecznym wielkopolskim dyskursie ${ }^{40}$.

Formą mecenatu społecznego były konkursy, ogłaszane $z$ reguły przez towarzystwa, redakcje czasopism, czasem miejscową administrację. Mimo że zarejestrowano ich kilkadziesiąt, w zasadzie tylko kilka dotyczyło podręczników czy literatury pedagogicznej. W odpowiedzi na konkurs Królewskiej Rady Szkolnej, K. Libelt napisał Wykład matematyki dla szkół gimnazjalnych (Poznań 1840), w ogłoszonym przez Dyrekcję Ligi Polskiej konkursie na trzy książki dotyczące historii Polski wydano dwie, autorstwa Bibiany Moraczewskiej i jedną Teodora Kilińskiego (ta, mająca 5 wydań, była polecana jako podręcznik w szkołach galicyjskich) ${ }^{41}$. W 1850 roku nie został rozstrzygnięty konkurs na dwa katechizmy ogłoszony przez arcybiskupa Leona Przyłuskiego ${ }^{42}$. W późniejszym okresie nie organizowano przez wiele lat konkursów na przygotowanie podręczników, a co najwyżej sięgano do książek z nurtu literatury ludowej, które mogłyby być wykorzystywane w wychowaniu domowym, samokształceniu (np. konkursy TCL). Interesującą w kontekście omawianych zagadnień inicjatywę podjęła redakcja „Oświaty” w 1867 roku, ogłaszając kilka konkursów, w tym na opracowania następujących tematów: Jak należy uczyć w szkołach naszych elementarnych historii naturalnej? Inny, O nauce geografii w szkołach naszych elementarnych czy Przyczyny zaniedbań u nas śpiewu kościelnego i świeckiego w ogóle, a w szczególności po szkołach elementarnych ${ }^{43}$. Dopiero pod koniec wieku XIX i na początku XX zauważyć można drobne w tym zakresie działania, choć nie zawsze przynoszące konkretny rezultat ${ }^{44}$. Podsumować ten wątek rozważań należy stwierdzeniem, że w Poznaniu konkursy nie odegrały znaczącej roli w kształtowaniu polityki wydawniczej.

Kończąc, należy stwierdzić, iż z uwagi na panującą sytuację produkcja książki szkolnej (podręcznikowej) oraz w szerszym ujęciu pedagogicznej nie zajęła w ofercie wydawców poznańskich znaczącego miejsca i poza kilkunastoma pozycjami nie przyniosła nadzwyczajnego plonu. Wydawało ją dość chętnie wielu wydawców, lecz wśród tych zawodowych trudno wskazać - może poza A. Poplińskim - takiego, dla którego stanowiłaby przedmiot specjalizacji czy szczególnego zainteresowania. Publikowaniem lub przynajmniej ich inicjowaniem zajmowały się także miejscowe towarzystwa i redakcje czasopism oraz oczywiście administracja

40 Podobne z założenia broszury, jak: T. Jackowskiego Pogląd na dawniejszą literaturę rolniczą polską, Poznań 1895; S. Robińskiego Pogląd ogólny na ruch literacki obecny nauki lekarskiej w Polsce, Poznań 1869, czy najogólniejsze z nich A. Białeckiego, Piśmiennictwo w W. X. Poznańskiem od r. 1850 i charakter tegoż w poprzedzających latach, Wilno 1858, podręcznikami nie zajmowały się.

${ }^{41}$ B. Moraczewska, Co się stało w Polsce od pierwszego jej rozbioru... (Poznań 1850); taż, Co się stało w Polsce od samego początku aż do pierwszego rozbioru kraju (Poznań 1852); T. Kiliński, Dzieje narodu polskiego (Poznań 1858, 1. wyd.).

42 „Szkoła polska” 1850, nr 21, s. 534.

43 "Oświata” 1867, z. 1, s. 64.

44 Konkursy: Centralnego Towarzystwa Gospodarczego owocujący Popularnym podręcznikiem chemii rolniczej Stanisława Mukułowskiego (Poznań 1897); Zjednoczenia Młodzieży Kupieckiej ukoronowany książką Korespondencja handlowa. Podręcznik dla młodzieży kupieckiej Tadeusza Adamczewskiego (Poznań 1911) oraz TCL z roku 1911 na napisanie nowego elementarza - nierozstrzygnięty. 
państwowa i miejscowy kościół. Publikacje w czasopismach oraz prowadzone dyskusje nie doprowadziły jednak przez cały wiek do wypracowania założeń polityki wydawniczej, w związku z czym oferta w wielu wypadkach była dość przypadkowa. Nie dopracowano się $w$ tym względzie tego, co udało się w odniesieniu do powiastki ludowej. W ocenie E. Pieścikowskiego, w drugiej połowie XIX wieku właśnie w wyniku dyskusji wypracowano w Poznaniu swoistego rodzaju powiastkę dla ludu, która wraz z formami pochodnymi określiła swoistą odrębność wielkopolskiego piśmiennictwa jako obiegu popularnego, o bardzo ważnych zadaniach do zrealizowania ${ }^{45}$. I bez wątpienia w wielu przypadkach ta literatura była „podręcznikiem" zarówno do nauki czytania, jak i kształtowania właściwych postaw, tak u młodych, jak i starszych wiekiem Wielkopolan.

${ }^{45}$ Por. E. Pieścikowski, „Ach! w tym Poznańskiem...” Życie literackie XIX wieku, Poznań 2003, s. 99-100, 105-111. 